\title{
PERBANDINGAN LATIHAN SENAM JUMSIHAT 1 DENGAN SENAM JUMSIHAT 2 TERHADAP KEBUGARAN JASMANI
}

\author{
Endah Listyasari \\ Fakultas Keguruan dan Ilmu Pendidikan Universitas Siliwangi
}

email : endah@unsil.ac.id

\begin{tabular}{l}
\hline Info Artikel \\
\hline Sejarah Artikel: \\
Diterima Desember 2018 \\
Disetujui Desember 2018 \\
Dipublikasikan Januari 2019
\end{tabular}

Keywords:

Senam, Jumsihat 1, jumsihat 2, kebugaran

\begin{abstract}
Abstrak
Upaya peningkatan kualitas kebugaran jasmani siswa ditempuh melalui Senam Jumsihat yang merupakan senam aerobik dengan perpaduan gerakan modern dan tradisional Jawa Barat. Hal ini terbukti pada Senam Jumsihat terdapat kolaborasi gerakan dasar beberapa cabang olahraga diantaranya tolak peluru, renang, dan olahraga daerah yaitu silat seperti kuda-kuda dan tangkisan. Tujuan dari penelitian ini adalah untuk memperoleh informasi tentang perbandingan pengaruh dari kedua bentuk latihan senam senam jumsihat terhadap peningkatan kebugaran jasmani Mahasiswa Pendidikan Jasmani Kesehatan dan Rekreasi Tingkat II Universitas Siliwangi Tasikmalaya. Metode penelitian yang digunakan adalah metode eksperimen dengan desain penelitian pre-test dan posttest. Populasi penelitian adalah Mahasiswa Pendidikan Jasmani Kesehatan dan Rekreasi Tingkat II Universitas Siliwangi Tasikmalaya sebanyak 179 orang. Sampel diambil secara acak sebanyak 20 orang menggunakan teknik Random Sampling. Berdasarkan hasil analisis data dan pembahasan hasil penelitian, penulis dapat menyimpulkan bahwa secara empirik latihan senam Jumsihat 1 dan senam Jumsihat 2 sama berpengaruhnya secara berarti terhadap kebugaran jasmani Mahasiswa Pendidikan Jasmani Kesehatan dan Rekreasi Tingkat II Universitas Siliwangi Tasikmalaya.
\end{abstract}

\section{Abstract}

Efforts to improve the quality of physical fitness of students are taken through Gymnastics Jumsihat which is an aerobic exercise with a combination of modern and traditional movements in West Java. This is evident in the Gymnastics Jumsihat there is a collaboration of basic movements in several sports including bullet, swimming, and regional sports, namely martial arts such as horses and defiance. The purpose of this study was to obtain information about the comparison of the effects of the two forms of gymnastic gymnastics training on improving physical fitness of Level II Physical Education and Recreation Students of the Siliwangi University of Tasikmalaya. The research method used is an 
experimental method with a pre-test and post-test research design. The study population was 179 Level II Physical and Recreational Health Education Students at the Siliwangi University, Tasikmalaya. Samples were taken randomly as many as 20 people using Random Sampling techniques. Based on the results of data analysis and discussion of the results of the study, the authors can conclude that empirically exercise Jumsihat 1 and Jumsihat 2 exercise are equally influential in terms of physical fitness of Level II Physical Education and Recreational Health Students of Siliwangi University Tasikmalaya.

(C) 2019 Endah Listyasari Under the license CC BY-SA 4.0

Alamat korespondensi: ISSN 2655-1896 (online)

E-mail : : endah@unsil.ac.id

ISSN 2443-1117 (cetak)

No Handphone : 082118264181 


\section{PENDAHULUAN}

Kebugaran jasmani merupakan derajat sehat dinamis seseorang. Derajat kesehatan menentukan kemampuan jasmani untuk dapat melaksanakan tugas yang harus dilaksanakan. Kebugaran jasmani seseorang adalah kemampuan tubuh seseorang untuk melakukan tugas pekerjaan sehari-hari tanpa menimbulkan kelelahan yang berarti. Setiap orang membutuhkan kebugaran jasmani yang baik adalah agar ia dapat melaksanakan pekerjaannya dengan efektif dan efisien tanpa mengalami kelelahan yang berarti. Tidak menimbulkan kelelahan yang berarti ialah setelah seseorang melakukan suatu kegiatan atau aktivitas, masih mempunyai cukup semangat dan tenaga untuk menikmati waktu senggangnya dan untuk keperluankeperluan lainnya yang mendadak.

Upaya peningkatan kualitas kebugaran jasmani siswa ditempuh melalui mata pelajaran Pendidikan Jasmani, Olahraga dan Kesehatan. Sebagaimana dikemukakan Depdiknas (2006 : 1-2) sebagai berikut:

Tujuan pendidikan jasmani dan kesehatan adalah membantu untuk meningkatkan derajat kesegaran jasmani, keterampilan gerak dasar, dan kesehatan melalui pengenalan dan penanaman sikap positif dan pematangan sikap mental yang diimplementasikan dalam berbagai aktivitas jasmani, agar dapat :

1. Mencapai pertumbuhan jasmani, khususnya tinggi dan berat badan yang ideal secara harmonis, dan perkembangan jasmani yang memiliki ketahanan yang memadai.

2. Meningkatkan sikap dan perilaku yang positif, seperti disiplin, kejujuran, kerjasama, menghargai orang lain, berjiwa kompetitif (bersaing) yang sehat, dan patuh terhadap peraturan dan ketentuan yang berlaku.

3. Menyenangi aktivitas jasmani dan olahraga yang dapat dipakai untuk pengisian waktu luang dan kebiasaan hidup sehat.

4. Meningkatkan kesegaran jasmani, keterampilan gerak dasar dalam berbagai cabang olahraga dan kesehatan yang baik.

5. Mengerti manfaat pendidikan jasmani dan kesehatan guna tercapainya kemampuan kehidupan yang seimbang.

Mata pelajaran Pendidikan Jasmani, Olahraga dan Kesehatan di sekolah yang sebenarnya merupakan langkah yang baik untuk membina kebugaran jasmani siswa, terkadang dikesampingkan. Cara ajar guru yang terkadang masih saja ada yang menggunakan gaya konvensional kurang mendukung siswa untuk melakukan gerak suatu cabang olahraga dengan baik dan benar, karena kurangnya pengawasan pendidik. Oleh karena hal tersebut keberadaan mata pelajaran tambahan atau sering disebut ekstrakulikuler sekolah sangat diminati oleh siswa. Terutama untuk siswa yang menempuh latihan-latihan kebugaran jasmani untuk olahraga prestasi.

Berbicara mengenai kebugaran jasmani pasti setiap orang menginginkan tubuhnya senantiasa sehat dan bugar, bagaimana menjaga kebugaran badan dapat dilakukan dengan berbagai cara. Salah satunya dengan melakukan olahraga yang bersifat aerobik. Olahraga aerobik adalah setiap jenis kegiatan fisik yang dilakukan pada tingkat intensitas sedang untuk jangka waktu tertentu. Aerobik adalah istilah umum yang digunakan untuk latihan yang menggabungkan beberapa elemen olahraga aerobik, peregangan, dan pelatihan kekuatan dengan tujuan utama meningkatkan kemampuan (fleksibilitas, kebugaran kardiovaskular, dan kekuatan otot) seseorang. Aerobik adalah salah satu jenis olahraga yang paling populer di masyarakat. Penggunaan musik, tari, peralatan dan fasilitas lainnya telah memberikan kontribusi terhadap popularitasnya. Dalam masa sekarang ini senam yang termasuk dalam olahraga aerobik sudah banyak dilakukan tiap sekolah. Salah satunya yaitu Senam Jumsihat.

Senam Jumsihat merupakan senam baru yang diperkenalkan oleh Silat Indonesia. Senam Jumsihat adalah singkatan dari Senam Jumat Bersih dan Sehat. Senam ini adalah senam aerobik 
yang merupakan paduan gerakan modern dan tradisional Jawa Barat. Hal ini terbukti pada Senam Jumsihat terdapat kolaborasi gerakan dasar beberapa cabang olahraga diantaranya tolak peluru, renang, dan olahraga daerah yaitu silat seperti kudakuda dan tangkisan. Bahkan instrumen pengiringnya pun ada irama Sunda yaitu kendang dan terompet. Senam jumsihat ini sasarannya adalah seluruh lapisan masyarakat Jawa Barat. Diperkenalkan untuk mengajak masyarakat untuk membiasakan hidup sehat dengan berolahraga lewat senam ini.

Gerakan-gerakan yang dilakukan dalam senam Jumsihat tidak sulit dilakukan anak-anak, remaja maupun orang tua, karena diciptakan secara sistemis dan terencana sehingga mudah untuk diikuti, dan dapat membawa manfaat bagi kebugaran jasmani bagi pelakunya. Selain itu juga di dalamnya mengandung unsurunsur rekreasi, dimana dalam melakukannya dapat menggunakan iringan musik dan berbagai gerakan yang menarik serta bervariasi, sehingga orang yang melakukan olahraga tersebut tidak cepat mengalami kejenuhan. Senam ini ada 2 macam dengan aliran yang masih sama yaitu senam Jumsihat 1 dan Senam Jumsihat 2 yang merupakan versi terbaru dari Senam Jumsihat 1. Untuk mahasiswa pasti tidak asing dengan program pelatihan senam. Biasanya senam sudah banyak dikenalkan ke masyarakat terutama dilingkungan pendidikan sejak SD.

Karakteristik dari Senam Jumsihat 1 mempunyai gerakan yang sederhana dan tidak terlalu banyak koordinasi gerakannya dalam satu koreo gerakan inti. Hitungannya 1x8 hitungan, pelaksanaannya terdiri dari 12 menit dengan gerakan pemanasan, gerakan inti, dan gerakan pendinginan. Sedangkan Senam Jumsihat 2 mempunyai gerakan dengan variasi gerak yang sedikit lebih variatif dalam satu koreo gerakan inti. Hitungannya 1x16 hitungan, durasi waktu pelaksanaan senam ini 12 menit yang didalamnya terdiri dari gerakan pemanasan, gerakan inti, dan gerakan pendinginan.

Melalui senam yang merupakan bagian dari pendidikan jasmani di sekolah dapat membantu peningkatan kebugaran jasmani dari siswa dan siswinya. Senam Jumsihat 1 dan Senam Jumsihat 2 merupakan alat yang sangat tepat dalam usaha mewujudkan tujuan pendidikan jasmani. Hal ini dapat dilihat bahwa kedua macam senam tersebut bukan hanya sebagai materi pelajaran yang disampaikan dalam mata pelajaran pendidikan jasmani, tetapi juga dicantumkan dalam program pendidikan yang dilakukan sebelum jam pelajaran dimulai. Kedua jenis senam tersebut dalam pelaksanaannya tidak harus dilakukan pada pagi hari saja, dapat dilakukan di mana saja, kapan saja, dan oleh siapa saja karena memang merupakan suatu bentuk kegiatan jasmani yang penting untuk menjaga, meningkatkan, dan menyempurnakan kebugaran jasmani.

Dari penjelasan di atas, maka melalui kegiatan senam tersebut siswa dapat dilatih unsur-unsur fisiknya. Sebagaimana dikemukakan Moeloek yang dikutip Dinata (2011 : 13), yang membagi komponen kondisi fisik atau kebugaran jasmani yaitu : "Daya tahan (endurance), kekuatan otot (muscle strength), daya ledak otot (muscle explosive power), kecepatan (speed), ketangkasan (ability), kelenturan (flexibility), keseimbangan (balance), kecepatan reaksi (reaction time), dan koordinasi (coordination)."

Untuk meningkatkan komponen kondisi fisik di atas, diperlukan suatu latihan yang dilakukan secara berkelanjutan dengan memperhatikan hal-hal yang berhubungan dengan program latihan seperti frekuensi latihan yang harus dilakukan setiap minggunya, intensitas latihan, dan lama latihan. Ketiga faktor tersebut sangat menentukan keberhasilan pelaksanaan program latihan. Sebelum melakukan tahap latihan seperti yang dijelaskan, alangkah baiknya melaksanakan terlebih dahulu tes untuk kebugaran jasmani untuk mengetahui kebugaran jasmani siswa sebelum mendapat pelatihan, sehingga kondisi kebugaran jasmani seseorang yang dilatih kondisi fisiknya akan terlihat jelas perbedaannya jika pada hasil akhirnya juga dilakukan tes akhir. 
Berdasarkan pengalaman penulis mengajar Mahasiswa Pendidikan Jasmani Kesehatan dan Rekreasi Tingkat II Universitas Siliwangi Tasikmalaya diketahui bahwa kebugaran jasmaninya rata-rata kurang baik, maka perlu diperlukan latihan yang dapat memacu meningkatnya derajat kebugaran jasmani.

Berdasarkan uraian di atas, penulis merumuskan masalah dalam penelitian ini sebagai berikut :

1. Apakah latihan Senam Jumsihat 1 berpengaruh terhadap kebugaran jasmani Mahasiswa Pendidikan Jasmani Kesehatan dan Rekreasi Tingkat II Universitas Siliwangi Tasikmalaya?

2. Apakah latihan Senam Jumsihat 2 berpengaruh terhadap kebugaran jasmani Mahasiswa Pendidikan Jasmani Kesehatan dan Rekreasi Tingkat II Universitas Siliwangi Tasikmalaya?

3. Manakah dari kedua bentuk latihan senam tersebut yang lebih berpengaruh terhadap kebugaran jasmani Mahasiswa Pendidikan Jasmani Kesehatan dan Rekreasi Tingkat II Universitas Siliwangi Tasikmalaya?

\section{METODE PENELITIAN}

Dalam suatu penelitian, pembuktian tentang kebenaran hipotesis yang diajukan harus ada. Untuk membuktikan kebenaran hipotesis yang diajukan itu, dalam penelitian tersebut diperlukan suatu metode. Mengenai metode Surakhmad (1998: 131) menjelaskan sebagai berikut:

Metode merupakan cara utama yang dipergunakan untuk mencapai suatu tujuan, misalnya untuk menguji serangkaian hipotesa, dengan mempergunakan teknik serta alat-alat tertentu. Cara utama itu dipergunakan setelah penyelidikan memperhitungkan kewajarannya ditinjau dari tujuan penyelidikan serta dari situasi paenyelidikan adalah pengertian yang luas, yang biasanya dijelaskan lebih eksplisit di dalam setiap penyelidikan.

Berhasil atau tidaknya suatu penelitian tergantung dari metode yang digunakan. Metode yang dipakai dalam penelitian ini adalah metode eksperimen. Mengenai metode eksperimen ini, Surakhmad (1998: 148) menjelaskan sebagai berikut, "Dalam arti yang luas, bereksperimen ialah mengadakan kegiatan percobaan untuk melihat sesuatu hasil".

Pertimbangan pengggunaan metode ini sesuai dengan dasar yang dikemukakan oleh Singarimbun (1999: 4) bahwa, "Penelitian eksperimen sangat sesuai untuk pengujian hipotesa tertentu dan dimaksudkan untuk mengetahui apakah variabel intervensi atau variabel eksperimen efektif atau tidak"

Berdasarkan penjelasan di atas, maka digunakannya metode eksperimen berarti penulis harus mengadakan percobaan terhadap sekelompok subjek yang akan menerima perlakuan tertentu dalam masa waktu tertentu. Dalam hal ini dengan menguji cobakan bentuk latihan Senam Jumsihat 1 dan Senam Jumsihat 2 untuk meningkatkan kebugaran jasmani Mahasiswa Pendidikan Jasmani Kesehatan dan Rekreasi Tingkat II Universitas Siliwangi Tasikmalaya.

Adapun populasi penelitian ini adalah seluruh Mahasiswa Pendidikan Jasmani Kesehatan dan Rekreasi Tingkat II Universitas Siliwangi Tasikmalaya dengan jumlah siswi 179 orang. Sedangkan untuk menentukan sampel dilakukan dengan cara acak sederhana (random sampling) dengan undian yaitu membuat tulisan pada kertas kecil-kecil yang sudah penulis tuliskan nomor-nomor yang mewakili sampel, diurutkan dari mahasiswa tingkat II, kemudian kertas tersebut penulis gulung, dan tanpa prasangka penulis mengambil 20 gulungan kertas dan nomor yang tertera pada gulungan tersebut merupakan nomor sampel penelitian penulis. Maka, sampel yang diambil dari seluruh populasi 
menggunakan random sampling yaitu sebanyak 20 orang Mahasiswa Pendidikan Jasmani Kesehatan dan Rekreasi Tingkat II Universitas Siliwangi Tasikmalaya.

Langkah-langkah yang penulis lakukan dalam penelitian ini adalah sebagai berikut:

1. Observasi pendahuluan ke objek penelitian

2. Menetapkan metode penelitian

3. Menentukan populasi dan sampel penelitian

4. Membagi sampel menjadi dua kelompok latihan

5. Menyusun instrumen penelitian

6. Melaksanakan tes awal

7. Melaksanakan latihan menggunakan Senam Jumsihat 1 pada kelompok A dan Senam Jumsihat 2 pada kelompok B.

Tabel 1 Deskripsi Data Hasil Penelitian Kelompok A
8. Melaksanakan tes akhir

9. Mengolah dan menganalisis data

10. Pengujian hipotesis

11. Mengambil kesimpula

12. Pelaporan hasil penelitian

\section{HASIL DAN PEMBAHASAN}

Data penelitian ini diperoleh dari hasil tes awal dan tes akhir butir-butir tes kesegaran jasmani indonesia (tkji) dari kelompok a (latihan senam jumsihat 1) dan kelompok b (latihan senam jumsihat 2). Data penelitian tersebut selanjutnya diolah dan dianalisis dengan pendekatan statistik untuk kemudian ditarik kesimpulannya. Berikut ini adalah deskripsi data hasil penelitian, sebagaimana tampak pada tabel 4.1 dan tabel 4.2 di bawah ini:

\begin{tabular}{|c|c|c|c|c|c|c|c|c|c|c|c|}
\hline \multirow{3}{*}{ No } & \multirow{3}{*}{ Nama } & \multicolumn{10}{|c|}{ Butir Tes } \\
\hline & & \multicolumn{2}{|c|}{$\begin{array}{c}\text { Lari } 50 \text { meter } \\
\text { (waktu dalam } \\
\text { detik) }\end{array}$} & \multicolumn{2}{|c|}{$\begin{array}{c}\text { Pull Up } \\
\text { (waktu dalam } \\
\text { detik) }\end{array}$} & \multicolumn{2}{|c|}{$\begin{array}{c}\text { Sit Up } 60 \\
\text { detik }\end{array}$} & \multicolumn{2}{|c|}{$\begin{array}{l}\text { Vertical } \\
\text { Jump }\end{array}$} & \multicolumn{2}{|c|}{$\begin{array}{l}\text { Lari } 800 \\
\text { meter (waktu } \\
\text { dalam menit) }\end{array}$} \\
\hline & & $\begin{array}{c}\text { Tes } \\
\text { Awal }\end{array}$ & $\begin{array}{c}\text { Tes } \\
\text { Akhir }\end{array}$ & $\begin{array}{c}\text { Tes } \\
\text { Awal }\end{array}$ & $\begin{array}{c}\text { Tes } \\
\text { Akhir }\end{array}$ & $\begin{array}{c}\text { Tes } \\
\text { Awal }\end{array}$ & $\begin{array}{c}\text { Tes } \\
\text { Akhir }\end{array}$ & $\begin{array}{c}\text { Tes } \\
\text { Awal }\end{array}$ & $\begin{array}{c}\text { Tes } \\
\text { Akhir }\end{array}$ & $\begin{array}{c}\text { Tes } \\
\text { Awal }\end{array}$ & $\begin{array}{c}\text { Tes } \\
\text { Akhir }\end{array}$ \\
\hline 1 & Khairin & 11.15 & 10.43 & 3.53 & 4.17 & 15 & 19 & 20 & 32 & 6.35 & 5.52 \\
\hline 2 & Firda & 11.08 & 9.37 & 4.02 & 5.54 & 18 & 21 & 26 & 40 & 6.2 & 5.29 \\
\hline 3 & Sabila & 12.3 & 11.12 & 4.55 & 6.05 & 26 & 34 & 30 & 45 & 6.41 & 6.05 \\
\hline 4 & Nela & 11.45 & 10.07 & 4.13 & 5.23 & 24 & 28 & 24 & 30 & 6.48 & 6.1 \\
\hline 5 & Putri & 12.24 & 11.23 & 4.22 & 5.37 & 15 & 20 & 25 & 33 & 7.16 & 6.52 \\
\hline 6 & Gesit & 11.52 & 10.35 & 5.11 & 6.19 & 24 & 29 & 32 & 43 & 6.21 & 5.38 \\
\hline 7 & Arina & 12.2 & 11.52 & 2.47 & 4.11 & 16 & 19 & 18 & 29 & 7.12 & 6.57 \\
\hline 8 & Rianti & 12.41 & 11.32 & 3.31 & 4.07 & 20 & 26 & 24 & 31 & 8.05 & 7.2 \\
\hline 9 & Wafiq & 12.3 & 10.57 & 4.31 & 5.12 & 18 & 23 & 31 & 47 & 7.17 & 6.5 \\
\hline 10 & Riska & 11.5 & 10.13 & 5.02 & 6.02 & 24 & 28 & 26 & 42 & 6.57 & 6.17 \\
\hline
\end{tabular}

Pengujian hipotesis bertujuan untuk membuktikan apakah hipotesis yang diajukan dalam penelitian ini diterima atau ditolak. Sehubungan dengan data dalam penelitian ini berdistribusi normal dan homogen maka uji hipotesis menggunakan uji kesamaan dua rata-rata (uji dua pihak). 
1. Analisis Data Hasil Latihan

Kelompok A (Latihan Senam

uji kesamaan dua rata-rata, yaitu uji t.

Jumsihat 1)

Adapun hasil pengujian untuk kelompok A

Untuk membuktikan kebenaran

dapat dilihat pada Tabel 4.6 di bawah ini.

hipotesis yang diajukan, maka digunakan

Tabel 2 Analisis Data Peningkatan Hasil Latihan Kelompok A

\begin{tabular}{cccc}
\hline Kelompok Latihan & Nilai $\mathbf{t}_{\text {hitung }}$ & $\begin{array}{c}\text { Nilai } \mathbf{t}_{\text {hitung } \text { dengan }} \\
(\boldsymbol{\alpha = 0 , 0 5 )} \mathbf{d a n} \mathbf{d k}=\mathbf{1 8}\end{array}$ & Kesimpulan \\
\hline 1. Tes Awal & & 2,10 & Signifikan \\
\hline 2. Tes Akhir & 4,44 & & \\
\hline
\end{tabular}

Berdasarkan tabel di atas, ternyata nilai $t_{\text {hitung }}$ sebesar 4,44 lebih besar dari $t_{\text {tabel }}$ dan berada di luar daerah penerimaan hipotesis nol ( $\mathrm{t}_{\text {tabel }}$ sebesar 2,10). Dengan demikian, hipotesis pertama yang diajukan terbukti atau diterima secara signifikan. Artinya, latihan senam jumsihat 1 efektif digunakan untuk meningkatkan kebugaran jasmani.

\section{Analisis Data Hasil Latihan Kelompok B (Latihan Senam Jumsihat 2)}

Sehubungan data hasil tes berdistribusi normal dan homogen, maka pengujian hipotesis dilakukan menggunakan uji kesamaan dua rata-rata (uji dua pihak). Adapun hasil analisis data dari kelompok b dapat dilihat pada tabel 4.7 di bawah ini.

Tabel 3 Analisis Data Peningkatan Hasil Latihan Kelompok B

\begin{tabular}{cccc}
\hline Kelompok Latihan & ${\text { Nilai } \mathbf{t}_{\text {hitung }}}^{\text {1. Tes Awal }}$ & $\begin{array}{c}\text { Nilai }_{\text {hitung }} \text { dengan } \\
(\boldsymbol{\alpha = 0 , 0 5}) \text { dan dk } \mathbf{~ 1 8}\end{array}$ & Kesimpulan \\
\hline 2. Tes Akhir & 6,30 & 2,10 & Signifikan \\
\hline
\end{tabular}

Berdasarkan tabel di atas, ternyata nilai $t_{\text {hitung }}$ sebesar 6,30 lebih besar dari $t_{\text {tabel }}$ sebesar 2,10 dan berada di luar daerah penerimaan hipotesis nol. Dengan demikian, hipotesis kedua yang diajukan terbukti atau diterima secara signifikan. Artinya, latihan senam jumsihat 2 efektif digunakan untuk meningkatkan kebugaran jasmani.

\section{Analisis Data Perbedaan Peningkatan Hasil Latihan Antara}

\section{Kelompok A Dengan Kelompok B}

Untuk mengetahui apakah peningkatan dan perkembangan dari kedua kelompok tersebut mempunyai perbedaan yang berarti atau tidak, maka dilakukan analisis terhadap perbedaan peningkatannya dengan menggunakan uji t. Adapun hasilnya dapat dilihat pada tabel $4.8 \mathrm{di}$ bawah ini. 
Table 4 Hasil Analisis Perbedaan Peningkatan Hasil Latihan antara Kelompok A dengan Kelompok B

\begin{tabular}{|c|c|c|c|c|}
\hline Kelompok Latihan & $\overline{\mathbf{X}}$ & $\begin{array}{c}\text { Nilai }_{\text {hitung }} \text { pada } \\
(\alpha=0,05)(18)\end{array}$ & $\mathbf{t}_{\text {hitung }}$ & Kesimpulan \\
\hline Kelompok A & 3,2 & \multirow{2}{*}{2,10} & \multirow{2}{*}{0,41} & \multirow{2}{*}{ Tidak Signifikan } \\
\hline Kelompok B & 3,4 & & & \\
\hline
\end{tabular}

Tabel Di Atas Menunjukkan Bahwa Nilai $T_{\text {hitung }}$ Sebesar 0,41 Lebih Kecil Dari $\mathrm{T}_{\text {tabel }}$ Dan Berada Di Dalam Daerah Penerimaan Hipotesis Nol $\left(\mathrm{T}_{\text {tabel }}\right.$ Sebesar 2,10), Sehingga Hipotesis Nol Diterima Dan Hipotesis Kerja Ditolak. Dengan Demikian, Hipotesis Ketiga Yang Diajukan Tidak Terbukti Atau Ditolak Secara Signifikan. Berdasarkan Perolehan Skor Rata-Rata Masing-Masing Kelompok Latihan, Maka Latihan Senam Jumsihat 1 Dengan Latihan Senam Jumsihat 2 SamaSama Memiliki Pengaruh Yang Berarti Terhadap Peningkatan Kebugaran Jasmani.

\section{SIMPULAN}

Berdasarkan hasil analisis data dan pembahasan hasil penelitian, penulis dapat menyimpulkan sebagai berikut:

1. Latihan Senam Jumsihat 1 berpengaruh secara berarti terhadap kebugaran jasmani mahasiswa pendidikan jasmani kesehatan dan rekreasi tingkat II universitas siliwangi.

2. Latihan Senam Jumsihat 2 berpengaruh secara berarti terhadap kebugaran jasmani mahasiswa pendidikan jasmani kesehatan dan rekreasi tingkat II universitas siliwangi.

3. Terdapat perbedaan pengaruh yang berarti antara latihan Senam Jumsihat 1 dengan Senam Jumsihat 2 terhadap kebugaran jasmani mahasiswa pendidikan jasmani kesehatan dan rekreasi tingkat II universitas siliwangi.

\section{DAFTAR PUSTAKA}

Adisasmito, L S. 2007. Mental Juara: Modal Atlet Berprestasi. Jakarta: Rajagrafindo Persada.

Eka Putra, Mulia. 2014. Efektivitas Latihan daya ledak otot lengan dan latihan kelentukan Terhadap Keterampilan front Handspring Atlet Senam Klub Bina Utama Kabupaten Pasaman. UNP : FIK

Anisa Herdiyana, 2011. Pembelajaran Pendidikan Jasmani Yang Mengacu Pada Pembiasaan Sikap Fair Playdan Kepercayaan Pada Peserta Didik. Jurnal Olahraga Prestasi, Volume 12, Nomor 1, Januari 2016

Hidayat, Imam. 2006. Senam.Bandung :Fakultas Pendidikan Olahraga dan Kesehatan Institut Keguruan dan Ilmu Pendidikan.

Husdarta. 2010. Psikologi Olahraga. Bandung: Alfabeta.

Iskandar, D. (2017). Pengaruh Pelatihan Kesegaran Jasmani Terhadap Prestasi Olahraga. JUARA : Jurnal Olahraga, 2(1), 11-17. Retrieved from

http://jurnal.upmk.ac.id/index.php/ju ara/article/view/28 
Komarudin. 2013. Psikologi Olahraga. Bandung : PT Remaja Rosdakarya

Mahendra, Agus. 2004. Senam Artistik. Bandung : UPI-FPOK

Novianti, W., \& Aji, S. (2016). Latihan Senam Aerobik Terhadap Dismenorea Saat Menstruasi Pada Anggota Senam. JUARA : Jurnal Olahraga, 1(1), 1-6. Retrieved from http://jurnal.upmk.ac.id/index.php/ju ara/article/view/58

Rahayu, Retno. 2007. Kontribusi kelentukan ke belakang, kekuatan otot lengan, otot perut, otot punggung, dan power tungkai dengan hasil handspring atlet senam putra jatim di surabaya. Unesa :fik-orkep ret-k.

Sarason I.G \&sarason, B.R, 1993. Abnormal Psychology. Tokyo: McGraw-Hill

Sibagariang, Dales Adi. 2013. Upaya Meningkatkan Kemampuan Hand Spring Di Lantai Melalui Alat Bantu Peti Lompat Yang Dimodifikasi Pada Atlet Putra Klub Senam Super Kids Medan.
UNIMED : Pendidikan Kepelatihan Olahraga.

Sugiyono. 2012. Memahami Penelitian Kualitatif. Bandung : ALFABETA.

Subekti, N. (2018). Tingkat Kebugaran Fisik Dasar Mahasiswa Pendidikan Olahraga. JUARA : Jurnal Olahraga, 3(2). Retrieved from http://jurnal.upmk.ac.id/index.php/ju $\underline{\operatorname{ara} / \operatorname{article} / \text { view/248 }}$

Werner, Peter H. 2012. Teaching Children Gynmastics. United States : by Peter H. Werner, H. Williams, Tina J.

Yuanita, Sari. 2011. Tips Menumbuhkan Motivasi dan Percaya Diri Untuk Meraih Kesuksesan.Yogyakarta: Brilliant Books.

Yuliyani Anik. 2014. Perbedaan Pengaruh Latihan Hand Spring Dengan Menggunakan Matras Gulung Dan Matras Lebih Tinggi Terhadap Kemampuan Hand Spring. UNS : FKIP-PJKR 